\title{
CORPORATE GOVERNANCE AND FIRM PERFORMANCE IN AN EMERGING MARKET: EVIDENCE FROM BARBADOS
}

\author{
Philmore Alleyne *, Renée M. Thompson ${ }^{* *}$ \\ * Corresponding author, Faculty of Social Sciences, The University of the West Indies, Barbados \\ Contact details: Department of Management Studies, Faculty of Social Sciences, The University of the West Indies, Cave Hill Campus, \\ Bridgetown, Barbados \\ ** Faculty of Social Sciences, The University of the West Indies, Barbados
}

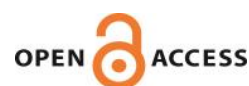

How to cite this paper: Alleyne, P., \& Thompson, R. M. (2019). Corporate governance and firm performance in an emerging market: Evidence from Barbados. Corporate Law \&

Governance Review, 1(2), 51-61. http://doi.org/10.22495/clgrvli2p5

Copyright $@ 2019$ The Authors

This work is licensed under a Creative Commons Attribution 4.0 International License (CC BY 4.0).

https://creativecommons.org/licenses /by/4.0/

\section{ISSN Online: $2664-1542$}

Received: 30.04 .2019

Accepted: 23.07.2019

JEL Classification: M14 DOI: $10.22495 /$ clgrvli2p5

\begin{abstract}
Good corporate governance practices are regarded as important in reducing risk for investors, attracting investment capital and improving the performance of companies. This paper investigates the relationship between corporate governance practices of the board of directors and firm performance of Colonial Life Insurance Company (CLICO), a large insurance company which collapsed in Barbados, and caused significant financial losses to policyholders. Using a case study approach, we used information from publicly available documents via print media and the internet to research the corporate governance practices and performance of CLICO. Findings reveal that the collapse of CLICO was a result of poor corporate governance mechanisms including lack of board independence, CEO and Chairman dual relationship, poor regulatory environment, non-functioning subcommittees, failure to manage risks, interlocking directorship, political involvement and lack of diversity. Recommendations include effective regulation, separation of the roles of CEO and Chairman, reduced political interference and more diversity.
\end{abstract}

Keywords: Corporate Governance, Board of Directors, CLICO, Barbados

Authors' individual contribution: Conceptualization - P.A. and R.M.T.; Methodology - P.A. and R.M.T.; Formal Analysis - P.A. and R.M.T.; Resources - P.A. and R.M.T.; Writing - P.A. and R.M.T.; Supervision - P.A. and R.M.T.

\section{INTRODUCTION}

Corporate governance is defined as "the mechanism for setting goals and objectives of the company and the means of achieving those goals and objectives" (Iqbal et al., 2019, p.2). It covers the activities of the board and its relationship with shareholders or members, and those involved in the affairs of the company including external auditors, regulators and other legitimate stakeholders (Tricker, 2015). Corporate governance is important for improving firm performance, investor confidence, economic efficiency, financial stability and market confidence (OECD, 2004). As a result, corporate governance establishes the rights and responsibilities among the various constituents such as the board, shareholders and other relevant stakeholders and sets clear guidelines for decision-making regarding the affairs of the organisation. Corporate governance is an internal control mechanism for monitoring management and is effective for helping a firm to attain good performance.

Studies on corporate governance and firm performance have been widely debated and well researched in developed countries. However, in the past few years, the topic has been given much discussion within emerging economies, given the range of corporate collapses and scandals resulting from weak systems of corporate governance (Arora \& Sharma, 2016). The manner in which corporate governance is organized differs among countries based on their political, social and economic development. In developed countries, firms have dispersed shareholders whereas developing countries have firms with family owned businesses and concentrated shareholders (Rafiee \& Sarabdeen, 2012).

Corporate scandals in the 1990's and early 2000 's including the global financial crisis of 2008 have emphasized the importance of corporate governance and the consequences of poor 
governance practices to governments, institutions and academics. Over the years, there has been the failure of large companies such as Enron and WorldCom which caused economies to plummet, and compelled changes to the way businesses are governed. In the Caribbean, there were similar occurrences of failures and collapses of companies that promoted unethical behaviour. For example, the failure of CLICO and the collapse of the Allen Stanford Empire in Antigua for engaging in a Ponzi scheme caused attention to be focused on bad management practices which resulted in financial burdens being placed on governments and investors within the region (Alleyne et al., 2014).

Global corporate failures saw the emergence of international standards, the enactment of new legislation, corporate governance codes and regulations. These emerging codes and recommendations included the Cadbury Code in the UK, the Sarbanes-Oxley Act in the USA, the Organisation for Economic Co-operation and Development (OECD) Principles of Corporate Governance and the Commonwealth Association of Corporate Governance Guidelines for Corporate Governance (Sookram, 2016). International institutions such as the World Bank and the OECD encouraged all companies to introduce standards of good corporate governance.

Prior studies have been conducted in developed countries with regards to corporate governance practices. In developing countries, the adoption of efficient and effective corporate governance can enhance managerial performance and assist with improving governance structures to increase capital and attract foreign investors. However, Chen et al. (2011) argued that corporate governance in developing countries is affected by weak legal controls, uncertain economies, poor investor protection and government intervention.

In the Caribbean, corporate governance studies have been limited to empirical research focusing mainly in the area of audit committees (e.g. Alleyne et al., 2014). Although many studies have investigated the relationship between corporate governance and firm performance in developed contexts (e.g. Jensen \& Meckling, 1976; Bhagat \& Black, 2001), few investigations have focused on corporate governance and firm performance in developing countries, particularly in Barbados. Additionally, lack of awareness and understanding of corporate governance structures, board practices, board composition, board characteristics and the role of boards of directors in the strategic decisionmaking process can be disadvantageous for Barbados. Furthermore, the absence of an established formal regulatory framework puts constraints on government and the private sector to develop a national corporate governance framework since there is little or no background information or no empirical data from which to reference.

There is a lack of academic research in corporate governance and boards of directors in developing countries, in particular Barbados. Accordingly, Alleyne et al. (2014, p. 187) opined that "with the collapse of the 2009 Colonial Life Insurance Company (CLICO) in Barbados' voluntary corporate governance environment, it is important for further research to be conducted to address the gap in the literature with respect to corporate governance practices in the Caribbean region". Moreover, corporate governance research in the Caribbean has been limited to the financial sector because of concerns about money laundering and terrorism financing. This caused the Central Bank of Barbados to improve the levels of supervision and regulation of financial institutions and adopt international standards of corporate governance.

Barbados is a small island which is located in the Eastern Caribbean ${ }^{1}$. It is an independent British Commonwealth country with an estimated population of about 287,000 people whose native language is English. The population is $90 \%$ black, a reminder of its African slave ancestry. However, the vast financial wealth is owned by the white minority who are descendants from Britain, springing their wealth from when their ancestors acted as merchants and plantation owners utilising slave labour to generate wealth from sugar. Thus, Barbados is referred to as "Little England" because of its British ties. Barbados has a common law system which practices the Westminster style of parliament, follows the English educational framework and adopts the Anglican religion from the Church of England.

Additionally, Barbados is one of fifteen territories that make up the Caribbean Single Market and Economy (CSME) and is considered to be a small developing state with an open economy. The culture of the island is closely knitted, socially integrated, traditional, hierarchical in structure and accepts the status quo with reverence for persons holding dignified posts (Alleyne, 2010). Barbados also has a sound democratic political structure. Its prime revenue earners are tourism, manufacturing, agriculture and offshore financial businesses (Alleyne et al., 2006).

The paper is structured as follows. Section 2 briefly reviews the literature, and is followed by a section on the legal overview of corporations in Barbados. The next section provides the facts and analysis of the CLICO collapse. The final section concludes the paper.

\section{BRIEF LITERATURE REVIEW}

\subsection{Definition of corporate governance}

The concept of corporate governance is framed within the principal-agent conflict and the reduction of agency cost caused by the separation of ownership and control (Berle \& Means, 1932). Corporate governance has been defined by many authors in different ways. Cadbury Report (1992) defines corporate governance "as the system by which companies are directed and controlled". It is concerned with the duties and responsibilities of the company's board of directors to successfully lead the company, and their relationship with the shareholders and other relevant stakeholder groups (Pass, 2004). The generally accepted definition of corporate governance, according to the OECD (2004), is the "procedures and processes according to which an organisation is directed and controlled". The corporate governance structure specifies the distribution of rights and responsibilities among

1 The Caribbean includes islands such as Barbados, Trinidad \& Tobago, Guyana, Jamaica and Antigua. 
different participants in the organisation such as the board of directors, managers, shareholders and other stakeholders.

From these definitions, it may be stated that different systems of corporate governance will embody what may be considered the legitimate lines of accountability by defining the nature of the relationship between the company and key constituents (Okpara, 2011). The concept of corporate governance is about having checks and balances in place to minimize problems associated with the principal-agent construct and to have effective mechanisms in place to control the opportunistic behaviour of the agent, thus ensuring that shareholders get the best returns on their investments (Wood \& Wood, 2013).

\subsection{Theoretical framework - Agency theory}

Corporate governance focuses on the problems arising between managers and shareholders (Jensen \& Meckling, 1976; Fama \& Jensen, 1983), which stems from the separation of ownership and control of companies (Berle \& Means, 1932), resulting in a principal-agent problem. An agency relationship is established when someone (the owner) hires another (the manager) to perform a task on his/her behalf. Consequently, as a corporate governance mechanism, the board of directors is viewed as a monitoring device to minimize problems brought about by the principal-agent relationship.

Jensen and Meckling (1976) posit that managers or directors are agents acting on behalf of the owners who have limited wealth at stake. Hence, their natural pursuit of self-interest could result in them taking riskier or even dishonest actions that could harm the firm or its owners. The agency theory assumes that agents tend to be selfish opportunists with various information asymmetries existing between knowledgeable agents and the principal. The theory assumes that agents will exploit owners (principals) unless controlled or incentivised not to do so (Miller \& Sardais, 2011). Likewise, Becht et al. (2005) argue that a corporate governance problem arises whenever an outside investor wishes to exercise control differently from the manager in charge of the firm. This situation gives rise to a principal-agent problem between controlling managers and weak dispersed shareholders. Once these problems come to the fore, they lead to agency cost which can be devastating.

Agency costs arise because shareholders who attempt to monitor managers, use incentives and contracts to align the interests of management and shareholders (Solomon \& Solomon, 2004). Agency problems can be manifested in two forms, adverse selection and moral hazard. Adverse selection can occur if the agent misrepresents his ability to perform the functions and is chosen by the principal. Moral hazard occurs when the chosen agent shirks the responsibilities or underperforms due to lack of dedication to one's duties and roles (Ujunwa et al., 2012). Therefore, the main purpose of agency theory is to provide assurance to shareholders that management is working towards achieving outcomes in their interest (Shleifer \& Vishny, 1997).

\subsection{Prior research on boards of directors and performance}

Boards are the internal governing mechanism that shape the firm's governance structure, given their direct access to managers and owners/shareholders. Primarily, a board of directors serves to make decisions on the business operations of the company and to monitor the activities of management. Boards of directors are expected to provide information and counsel to managers, address corporate strategy, safeguard the interest of shareholders, monitor and control the actions of managers, link the corporation to the external environment and monitor compliance within the applicable laws.

Boards of directors are staffed with individuals elected by the shareholders to act on their behalf and to monitor top management (Fama \& Jensen, 1983). Corporate boards generally include inside directors (executive directors) and outside directors (non-executive directors) who often hold the majority of positions on the board. Outside board members may act as arbiters in disagreements among internal managers or with issues concerning management such as setting executive compensation or searching for replacements for top managers (Fama \& Jensen, 1983). Boards of directors hire and fire management as well as assess their performance. The board also serves as a source of advice and counsel for management and sets the strategic direction of the company by implementing the policy in which projects are selected (Fama \& Jensen, 1983).

The board of director's structure is considered to be a primary way for stakeholders to have control over top management (Hassan et al., 2017). Therefore, it is essential for a firm to have a board that is independent from the influence of management to ensure effective monitoring (Nazir et al., 2009). The Cadbury Report (1992) posits that the presence of independent directors should be effective in enhancing board independence and performance. The code of best practice recommends that the board should include non-executive directors of such calibre and numbers, thus enabling their views to carry significant weight in the board's decisions. Empirical findings on the relationship between the proportion of non-executive directors and firm performance are mixed. Prior research finds that the performance of firms is more likely to increase with the independence of their boards (Hermalin \& Weisbach, 1991; Bhagat \& Black, 2001).

Additionally, prior research has found a positive relationship between board size and firm performance for large companies (Kiel et al., 2003; Zubaidah et al., 2009). A large board size is argued to benefit corporate performance (Arora \& Sharma, 2016; Ozgur et al., 2010). It enhances the ability of the firm to establish external links with the environment, secures other rare resources and attracts exceptionally qualified counsel (Dalton et al., 1998). Large boards also provide greater diversity, skills and can better restrict the opportunistic behaviour of management (Forbes \& Milliken, 1999; Moreno-Gómez et al., 2017). Conversely, Lipton and Lorsch (1992) note that large boards face problems of social loafing, free-riding and poor coordination (Ntim et al., 2015), thus 
reducing the efficiency of the board. Other researchers give support for small boards (Jensen, 1993; Yermack, 1996). Eisenberg et al. (1998) report a negative relationship between board size and profitability in small and medium Finnish firms. Paniagua et al. (2018) find an inverse relationship between board size and financial performance in firms. Lipton and Lorsch (1992) have argued that board size should be small with a maximum of eight members. Prior research has shown that smaller boards are associated with higher firm value (Yermack, 1996; Eisenberg et al., 1998). MorenoGómez et al. (2017) suggest that the relationship between board size and firm performance may be explained by agency theory.

Board expertise refers to the skills and knowledge of individual board members which could develop from education and various experiences. The educational qualification of directors is important for decision-making. Akpan and Amran (2014) posit that boards with educated directors tend to perform better than those with uneducated directors. Studies have found that boards with higher levels of expertise, experience high levels of firm financial performance and exhibit reduced incidences of restating earnings (Ujunwa, 2012; Agrawal \& Chandra, 2005).

Miyienda et al. (2013) find a positive relationship between board remuneration and firm performance. Lee et al. (2008) also provide evidence that effective corporate governance strengthens the positive relationship between firm performance and pay dispersion (i.e. greater incentives to highly qualified managers). Hence, agency costs are reduced and firm performance improved by providing good remuneration packages.

Prior research suggests that women are particularly valued as board members for their ability to provide strategic input and generate more productive discourse (Nielsen \& Huse, 2010; Sarhan et al., 2019) which is reflected in their participative management style (Pearce \& Zahra, 1992). Studies conducted on the relationship between women on boards and firm performance in different jurisdictions are mixed and inconclusive (Ujunwa et al., 2012). Smith et al. (2005) find that the proportion of women on boards has a positive effect on firm performance. However, Cucinelli (2013) finds a negative relationship between the number of women on boards and financial performance. Wachudi and Mboya (2012) find no significant relationship between the presence of female directors on boards and performance of commercial banks in Kenya.

To mitigate the agency problems and cost, separation of the role of CEO and chairman is highly recommended (Jensen, 1993). Cadbury (1992) recommends that the role of chairman should be separated from that of the CEO because the two roles combined represent considerable power within the decision-making process (Arora \& Sharma, 2016). This view is also supported by other reports (Greenbury 1995; Higgs, 2003). Based on the code of corporate governance in Barbados, the chairman of the board and the CEO's position should be separated in the company. Several studies examine the relationship between CEO duality and firm performance but the results have been inconsistent. Rashid (2010) and Abdallah (2004) find that there is a non-significant relationship between CEO duality and firm performance. Conversely, Brickley et al. (1997) show that CEO duality is not associated with inferior performance.

The effectiveness of boards can be further enhanced by establishing oversight board committees comprising the majority of independent directors (Lam \& Lee, 2012). Cadbury Report (1992) highlights the importance of board committees and recommends that the board should establish subcommittees such as audit, remuneration and nomination committees. Klein (1998) finds a weak positive relationship between the presence of remuneration committees and firm performance. However, McMullen (1996) finds that the presence of an audit committee is positively related to more reliable financial reporting, less errors and fewer irregularities.

\section{LEGAL OVERVIEW OF CORPORATIONS IN BARBADOS}

The company structure in Barbados is basically of three types: sole proprietorships, partnerships or limited liability companies. Companies (incorporated entities) include private and public limited liability companies. At present, there are 22 public limited liability companies (PLCs) listed on the Barbados Stock Exchange (BSE). The BSE is expected to regulate all listed companies on the exchange market and has already outlined a set of corporate governance recommendations for them. Moreover, the BSE recognizes that by having sound corporate governance practices, a company will remain profitable during challenging economic times.

PLCs in Barbados are also required to comply with the requirements of the Barbados Companies Act Cap.308, which closely follows the British Companies Act (Government of Barbados, 2001). The Act also set guidelines with regards to the roles, responsibilities and rights of shareholders, directors, auditors, audit committees and other parties. PLCs in Barbados are required to publish annual reports but do not have to disclose their corporate governance practices. PLCs must report any changes subsequent to registration on the exchange to the BSE. Therefore, corporate governance disclosures of listed companies are voluntary. Meanwhile, major issues of corporate governance in Barbados include the lack of a formal governance framework, interlocking directorships and a bias in the selection of individuals to serve on various boards (Alleyne et al., 2014).

The business practices of Barbadian companies are influenced by the accounting profession including governance practices of developed countries, as well as attempts at following international best practices based on pressures from international lending agencies such as the International Monetary Fund (IMF) and the InterAmerican Development Bank (IADB). Thus, companies in Barbados have adopted in varying degrees aspects of international best practices of corporate governance from the 2002 Sarbanes-Oxley (SOX) Act, the International Accounting Standards (IAS) and the OECD. In addition, the professional accounting associations of developed countries such as the Association of Certified and Chartered Accountants (ACCA) in the UK, the Certified General 
Accountants (CGA), Certified Management Accountants (CMA) in Canada, and Certified Public Accountants (CPA) in the United States have also influenced accounting practices and corporate governance cultures in Barbados (Alleyne et al., 2006). The accounting profession is regulated by the Institute of Chartered Accountants of Barbados (ICAB), which is a member of the International Federation of Accountants (IFAC) in order to achieve institutional legitimacy.

Accordingly, in Barbados, the adoption of corporate governance codes such as the OECD guidelines is not mandated, hence its adoption by businesses is voluntary. The OECD (2004) states that a corporate governance framework will comprise elements such as legislation, voluntary commitments and business practices that are based on a country's specific structure. Therefore, as business circumstances change, the structure and framework may need to be adjusted (OECD, 2004).

The Central Bank of Barbados was first established in 1972 to aid government in the implementation of monetary policies and governance in Barbados. In the aftermath of global and regional collapses of companies, the Financial Services Commission (FSC) was established in 2010 to help with governance of financial institutions within Barbados. The Central Bank of Barbados and the FSC identify that the board of directors have an overall responsibility for the quality of governance, which includes approving and overseeing the implementation of the strategic objectives, risk strategy, corporate governance framework and corporate values of the organization. The board is also responsible for providing oversight of senior management as well as ensuring that the day to day activities of the company run smoothly.

The Central Bank of Barbados guidelines dictate that the board has an oversight role designed to ensure that the licensee (the company) is managed in a way that safeguards safety, soundness and is in compliance with all relevant laws and regulations. Similarly, the FSC has set out comprehensive regulations with regards to what purpose the board of directors should serve. For instance, the board of directors should among other things:

- ensure that the financial institution has a balance of appropriately skilled, experienced and qualified individuals who can apply informed and independent judgment to the management of financial institutions;

- ensure that the financial institution is effectively managed, by appointing the financial institution's CEO or Managing Director, and ensuring that its business is conducted in a sound and prudent manner by establishing relevant objectives and performance measures which are monitored on a regular basis;

- meet regularly and oblige members to devote sufficient time to their board responsibilities, inclusive of receiving, examining and approving reports required for sound financial management, monitoring the institution's financial condition and ensuring that the institution's reputation and integrity is sustained;

- establish and document its strategic objectives, the means of obtaining objectives and procedures for monitoring and evaluating its progress in achieving these objectives;

- establish and document the nomination and appointment procedures, structure, functions, reelections and balance between executive and nonexecutive directors of the board in a transparent manner;

- clearly distinguish between responsibilities, accountabilities, decision-making, interaction and cooperation of the board of directors, chairman, chief executive officer and senior management;

- outline a clear division of responsibilities to ensure a balance of power and authority, so that no individual has unfettered powers of decision. Where the posts of chairman and chief executive officer (CEO) are combined into one person, evidence that appropriate controls are in place to ensure that management is sufficiently accountable to the board of directors should be provided;

- have access to accurate, relevant and timely information. Where stakeholders participate in the corporate governance process, they should have access to relevant information.

\section{ANALYSIS OF CORPORATE BOARD PRACTICES IN BARBADOS}

\subsection{CLICO case - The introduction ${ }^{2}$}

Colonial Life Insurance Company Limited (CLICO) was one of the largest insurance companies in the Caribbean region. The flagship of the parent company, CL Financial (CLF), was the largest privately-owned conglomerate in the Commonwealth Caribbean (Soverall, 2012). Its business operations spanned insurance, financial services, real estate development, manufacturing, agriculture, forestry, retail, distribution, energy, communications and media. CLF operated in 32 countries through its associated and joint venture companies and established more than 65 subsidiaries which spanned the Caribbean, Florida, Europe, the Middle East and Asia. The principal subsidiaries in Barbados were CLICO International Life Insurance Co Ltd, CLICO Mortgage and Finance Co Ltd, CLICO International General Insurance Co Ltd and CLICO Holdings.

The parent company, which was based in the Republic of Trinidad and Tobago, controlled in excess of TT $\$ 100$ billion and 55\% ownership of Republic Bank ${ }^{3}$. Thus, CLF was poised to be an example of success in this region. Soverall (2012) noted that the parent company was "very conscious of the contagion risks that the financial collapse of an institution as vast as CLF could have on the entire financial system of the entire Caribbean region". In fact, it was argued that due to the size of CLICO, regulatory authorities of both Barbados and Trinidad should have recognized the impact of any possible crises arising within the company and its effect throughout the region (Alleyne et al., 2014). In January 2009, the parent company in Trinidad collapsed. Thus, the collapse of CLICO threatened

${ }^{2}$ This case was developed via data collected from internet sources, journal articles, newspaper articles, commentaries, court documents and other publicly available documents.

${ }^{3}$ The currency of Trinidad and Tobago is termed as TT\$. The currency exchange is 1TT $=0.15$ US\$. 
the interest of depositors, policy holders and creditors, thereby posing a danger of disruption and damage to the financial system. After the collapse, governments across the region sought to stem fallouts and minimize the contagion effects.

Table 1. CLICO Group of companies in Barbados

\begin{tabular}{|l|l|}
\hline \multicolumn{2}{|c|}{ CLICO Group In Barbados } \\
\hline 1. & CLICO Life Insurance Limited (CLICO) \\
\hline 2. & CLICO Holdings (Barbados) Limited \\
\hline 3. & Rayside Construction Limited Barbados \\
\hline 4. & Rayside Construction Limited Trinidad \\
\hline 5. & Cotton Park Corporation \\
\hline 6. & Clermont Development Incorporated \\
\hline 7. & Southdown Enterprises Incorporated \\
\hline 8. & CLICO Financial Complex Limited \\
\hline 9. & Grant Hotels Incorporated \\
\hline 10. & Wakefield Plantation \\
\hline 11. & Todds Estates Limited \\
\hline 12. & British American Insurance Company Limited \\
\hline
\end{tabular}

Table 1 shows the CLICO group of companies operating in Barbados at the time of the collapse. Many Barbadians invested in CLICO Barbados. Retirees invested their gratuities from employment and others continually deposited funds for life insurance and pension plans.

Table 2 shows the members of the board of directors of CLICO Barbados.

Table 2. Board of Directors of CLICO Barbados ${ }^{4}$

\begin{tabular}{|c|c|}
\hline Names \& profession & Names \& profession \\
\hline Leroy Parris (CEO/Chairman*) & David Griffith (Accountant ${ }^{* * *}$ ) \\
\hline Leslie Haynes (Attorney at Law ${ }^{* * *}$ ) & Vishnu Ramlogan (Businessman***) \\
\hline Tony Marshall (Retired Banker**) & $\begin{array}{c}\text { Terrence Thornhill (President, } \\
\text { CLICO Holdings } \\
\text { Barbados Ltd*) }\end{array}$ \\
\hline $\begin{array}{c}\text { Woodbine Davis (Former Solicitor } \\
\text { General, Attorney at } \\
\text { Law }^{* * *} \text { ) }\end{array}$ & Dr. Frank Alleyne (Economist ${ }^{* *}$ ) \\
\hline $\begin{array}{l}\text { Dr. Basil Springer (Management } \\
\text { Consultant }{ }^{* * *} \text { ) }\end{array}$ & $\begin{array}{c}\text { Lawrence Duprey (Businessman \& } \\
\text { Chairman, CLF*) }\end{array}$ \\
\hline $\begin{array}{c}\text { Anthony Ellis (Chartered } \\
\text { Accountant } * *)\end{array}$ & Brian Branker (Chairman, BAICO*) \\
\hline $\begin{array}{l}\text { Dr. Adrian Lorde (Medical } \\
\text { Doctor } * *)\end{array}$ & $\begin{array}{l}\text { Robert Fullerton (Director, } \\
\text { BAICO*) }\end{array}$ \\
\hline Elridge Thompson (Director" & \\
\hline
\end{tabular}

On April 14, 2011, the Supreme Court of Barbados appointed Deloitte Consulting Ltd as judicial manager of $\mathrm{CLICO}^{5}$. The judicial manager issued an interim report on May 27, 2011 which showed the company's total assets were BDS \$802 million, of which BDS $\$ 370$ million represented amounts receivable from related companies (Deloitte, 2011) ${ }^{6}$.

On September 20, 2011, the Supreme Court approved the judicial management's recommendation for a forensic audit to be done by Deloitte and Touche LLP in Canada. Based on the activity in the inter-company accounts, CLICO acted as the bankers for its related companies. In a further

\footnotetext{
${ }^{4}$ Source:http://www.caribbean360.com/news/clico_chairman_calls_it_quits ${ }^{5}$ As part of a financial rescue programme, a judicial manager is appointed by the Court when a company is deemed to be insolvent. The Judicial Manager takes over the management of the company, meets creditors and other stakeholders, and reports to the Court.

6 The currency of Barbados is termed as BDS \$. The currency exchange is 1BDS $\$=0.50$ US $\$$.
}

report by its Judicial Manager dated July 28, 2011, amounts due from related companies were BDS $\$ 376$ million with a forced liquidation value estimated to be BDS $\$ 177$ million, thus suggesting that there was the likelihood that the intercompany balances may not be fully recovered. The report noted that "...the company is chronically short of the necessary assets to cover its policyholder liabilities and as such the shareholders of the company have no residual equity interest". Further to this, in a report on March 31, 2012, Deloitte (2013a) assessed the net book value of CLICO's assets at BDS $\$ 764,524,882$ (Fair market value BDS $\$ 441,013,220$ ) and total policyholders' liabilities of BDS $\$ 837,435,072$.

On July 27, 2013, Barbados' Investors and Policyholders Alliance (BPA) (a group of policyholders and investors seeking to recover their investments) sued 13 directors of the insolvent CLICO and British American Insurance Company (BAICO) in negligence lawsuits totalling BDS \$128 million (Stabroek News, 2013).

In January 2018, the Government of Barbados set up a new company to control the Barbados-based life insurance portfolio previously held by CLICO International Life Insurance (CIL) with the objective to settle outstanding payouts to former policyholders. The court-approved new company, Barbadian-owned Resolution Life Assurance Company Limited (ResLife) promised to speedily address the BDS $\$ 91$ million (US $\$ 45.5$ million) in outstanding settlements (Caribbean360, 2018).

\subsection{Weak governance environment}

Soverall (2012) noted that regulators of the entity were not at all blameless in terms of the collapse of the parent company, CLF. In fact, Layne (2010) noted that in August 1998 a report was prepared in the Office of the Supervisor of Insurance of the parent company which indicated a 5-year review of CLF from 1992 to 1996. The report indicated that CLF since 1992 found "it difficult to satisfy" its Statutory Fund Requirement ${ }^{7}$. Nevertheless, CLF declared and paid dividends in 1993, 1994 and 1995. Moreover, CLF proposed the payment of dividends for 1996 which was in violation of the Insurance Act. The report also highlighted that insolvency problems were getting progressively worse. Ewart Williams in April 2010 in Trinidad concluded that the "soft touch approach to regulation" led to the excesses which caused the crisis. In Barbados, similar deficits in the statutory fund occurred since 2004. Indeed, Stabroek News (2009) reported that there was a statutory fund deficit of BDS \$93 million since 2007. Criticisms were levelled at the Office of Supervisor of Insurance, the regulatory body responsible for monitoring CLICO. However, it was perceived that the "soft approach to regulation" (hands off CLICO) was based on the close relationship between CLICO and the political parties.

The Executive Chairman of CLICO Holdings (Barbados Ltd) had previously tried to persuade the Barbadian clientele that there was no connection

${ }^{7}$ Stabroek News (2009) explains that the "Statutory Fund, required by Section 25 of the Insurance Act Cap 310 of the Laws of Barbados, was a fund in which the insurance company must place in trust, enough assets to match their liabilities so as to protect policy holders, in the event of there being financial difficulties that would make it difficult for the insurance company to meet its obligations to policy holders". 
between the Barbadian entity and its Trinidadian parent which collapsed first. However, both companies followed similar paths. It was also suggested that the auditors never highlighted any major issues or going concern problems in their audit reports. Indeed, no person has been charged for the wrongdoing to date. CLICO, a company regarded as a successful conglomerate and a prime example of financial and regional integration was largely unregulated by the state. Thus, its failure and collapse negatively impacted the financial systems in almost every Caribbean country in which it operated.

\subsection{Lack of effective subcommittees}

CLICO had no functioning committees to deal with audit, risk, corporate governance and investment issues (Sookram, 2016). In fact, the audit committee scarcely met to tackle auditing issues. The board adopted the advice of the CEO and Executive Management. Hence, an agency problem existed whereby there was no proper monitoring function performed by the subcommittees. The lack of effective subcommittees was a major weakness in corporate governance practices within the company. Furthermore, the failure to have an effective working audit committee compromised independence and hindered its role to have oversight of the company (Lam \& Lee, 2012; Alleyne at al., 2006).

\subsection{Political relationships}

CLICO (Barbados) had political ties with the Government of Barbados, since it made financial contributions to political campaigns. For example, based on the forensic audit conducted by Deloitte Consulting Ltd, a sum of BDS $\$ 3.333$ million was paid to Thompson and Associates (a law firm in Barbados) by CLICO (Barbados) in January 2009 (Deloitte, 2011). On hearing of the collapse of the parent company in Trinidad, Mr. David Thompson (the Prime Minister of Barbados at the time) hastily submitted an invoice on Thompson and Associates letterhead for a retainer and legal fees in the amount of BDS \$3.333 million. It was later found that the invoice was fictitious as Mr. Thompson had left the practice of Thompson and Associates a year earlier to take up the Prime Ministership. In fact, the true purpose of the invoice was to benefit Mr. Leroy Parris (former chairman and CEO of CLICO Barbados and CHBL) in the form of a gratuity (Deloitte, 2013b). Political links on the board, the economic influence of the company and weak supervision by the state regulatory body contributed to CLICO's collapse (Alleyne \& Pierce, 2017).

\subsection{Ineffective board function - Failure to assess risks}

In addition, another issue was the board's reluctance to take an active role in the levels of risk management either because the board did not have the requisite knowledge or the board did not wish to offend management. Today, boards are being called upon to be risk intelligent to meet their fiduciary responsibility by sharing a common vision of risk and adopting a framework to support their risk oversight activities. To mitigate any ramifications associated with risks taken by the management of the company, the directors must be satisfied that the risk management policies and procedures are in place to deal effectively with the company's risk strategy and appetite. In CLICO's case, the board did not fully assess the company's risk processes.

Investigations showed that there were several factors that sparked the collapse of CLICO. These ranged from liquidity challenges arising from intergroup transactions and high levels of withdrawal requests, to concerns about the impact of the sharp decline in methanol and real estate prices. There were also characteristics present in some of the subsidiaries of the conglomerate similar to that of Ponzi and Pyramid schemes. CLICO's business model was high-risk and dangerously flawed. The collapse of CLICO illustrated that weak risk management practices and inadequate management information were major contributing factors to its demise (Alleyne \& Chandler, 2018)

\section{6. $\mathrm{CEO}$ and chairman dual roles}

The Chairman/CEO of CLICO had no qualifications or expertise to run the organization. The deficiencies in the corporate governance structure of the company in Barbados saw that the chairman was also the CEO which gave him significant control and leadership in the organization and its decisionmaking processes (Soverall \& Persaud, 2013). He led from the front and did not entertain any opposition to his plans from board members and employees within the organization. The board had little or no concern for professional advice or appropriate discussions on issues that were central to the company. The board comprised directors who were not independent, thus empowering the Chairman/CEO. The chairman disapproved board decisions at will and the board approved the chairman's decisions which led to minimal conflicts. The practice of Chairman/CEO duality in CLICO contradicted the arguments for separation of the role of CEO and chairman in prior literature (Jensen, 1993; Alleyne et al., 2014). In CLICO, considerable power was vested in one individual, thus creating a corporate governance challenge.

\subsection{Interlocking boards}

The group of companies also had issues of significant interlocking boards especially CLICO and BAICO in Barbados. The difficulty arose where fiduciary responsibilities (duty of care in the interest of each company) were blurred with likely conflicts arising. It was found that the board of directors acted in the interest of the group instead of the interest of each entity, thus reflecting an agency problem. This type of governance structure of the company highlighted a breach of corporate governance principles for the separation of function and powers. In a small society like Barbados, boards should be independent; however, relationships are inevitable as directors sit on multiple boards together. This practice could destroy the objectivity of decision-making and information spill-over especially if there are companies competing against each other. Directors are also unable to contribute at meetings due to fatigue (Alleyne et al., 2014). In addition, the development of friendships among members of a board of directors means that when 
motions are placed on the table, bias in decisionmaking would take precedence because of loyalties to friends rather than loyalties to the stakeholders.

\subsection{Board composition}

The CLICO board consisted of members who were business associates or friends of the Chairman/CEO. There was no documentation of any objective criteria for appointment to the board. Board composition should include a mixture of members who are diverse in skills and experience relevant to the organization's business. Similarly, to be an effective board, each individual board member is required to have diverse skills, experience, personal attributes and approaches with the aim of increasing board independence, effectiveness and competency. In addition, investors are becoming more vocal about the tenure of board members when independence has become blurred based on the length of time a director has been on the board. The CLICO board became a "yes board" by agreeing to every decision made by a CEO/Chairman who had no qualifications in the area of insurance or running an organization. Table 2 showed that there was no gender diversity on the board. It was predominately male. In addition, the level and range of expertise of board members were quite limited, given the diverse business activities in the group and the related complexity. Thus, composition of the board of CLICO contradicted prior literature which finds organizational performance is positively influenced by expertise and experience (Akpan \& Amran, 2014) and gender diversity (Sarhan et al., 2019).

\subsection{Board minutes}

Evidence showed that meetings and recording of minutes were below par. Indeed, the existing minutes highlighted inadequate procedures for approval on decisions made. For example, Deloitte (2011) reported that "In certain cases (at least until the appointment of the Oversight Committee) the wording of the minutes suggests that the Board was informed of transactions only after CIL or CHBL was committed to them by executive management. In other cases, the extent to which the Board was consulted and provided its input and approval before concluding transactions, if at all, is not clear from the minutes. Most of the ratifications of the directors related to the reappointment of auditors, directors' approval of minutes and approval of audited financial statements". The conduct of board meetings and the related recording and approval of minutes are effective corporate governance practices. Thus, the ad hoc approach to meetings and inadequate recording of minutes of meetings in CLICO seem to reflect ineffective corporate governance practices which could have led to poor decision making (Alleyne \& Pierce, 2017; Ujunwa, 2012).

\section{CONCLUSION}

This study explored the impact of board independence, board composition, CEO duality, board size, professional expertise, board committees and diversity in a large company in Barbados, CLICO, using a case study approach. Findings revealed that the collapse of CLICO was a result of poor corporate governance mechanisms including lack of board independence, CEO and Chairman dual relationship, poor regulatory environment, non-functioning subcommittees, failure to manage risks, interlocking directorships, political involvement and lack of diversity. The study showed how the corporate governance practices of the board of directors caused CLICO to perform poorly and eventually placed under judicial management.

Additionally, in Barbados, the constraints that hinder the implementation of good corporate governance includes a weak or non-existent regulatory framework, lack of transparency and disclosure, weak enforcement and poor monitoring systems. Barbados has laws that offer protection of shareholders which include improving transparency, disclosure and accountability but cultural issues can pose a challenge to stakeholders. Yet very little pressure is being exerted by the regulators towards the implementation of a sound corporate governance framework.

Given that there is a limited pool of individuals who are willing to serve as directors in Barbados, there may be some bias among directors on boards. Consequently, this study will add to the literature on corporate governance practices from the perspective of an emerging economy by contributing to the development of corporate governance in Barbados with the implementation of best practices. It is hoped that further research will explore the issues highlighted by this study and that reform of corporate governance practices in organizations will be initiated by the board of directors towards an effective corporate governance system in the interest of shareholders. Moreover, it should be noted that corporate governance mechanisms implemented in other countries may not be best fit for Barbados.

The barriers to effective corporate governance practices must be overcome. This can be achieved by boards of directors taking a more holistic view of their responsibilities by realizing that they are trustees of the wealth assigned to them through the shareholders for social good rather than personal gain.

Regulators should also impose stringent penalties for those who practice poor corporate governance. Board members should receive ongoing training and education in leadership and effective corporate governance practices. Directors should be appointed based on ability or qualifications and should be aware of the company's financial performance as well as actively participate in board meetings.

Diversity of skills is fundamental for effective risk management and succession planning. The diversity of board composition should encompass individuals of different ages, gender, experience and qualifications to support better decision making. The separation of the chairman and CEO provides no guarantee of better leadership. However, given the CLICO fiasco in 2009, it is recommended that the position of Chairman be separated from that of the CEO. Effective corporate governance can also be achieved through communication and interaction with the company's investors and other stakeholders to build and restore trust and credibility. The appointment of a foreign independent director to sit 
on boards can provide valuable international expertise about corporate governance best practices which can make boards more effective at monitoring management.

Finally, companies can benefit from effective corporate governance practices through better strategic decision making, greater economic value creation, improved management, control of risk and enhanced regulatory compliance. Consequently, any change towards sound corporate governance should be driven by the board and its chairman who must set the tone at the top.

This study has several limitations. First, the study reports the results from a single case study, and consequently a single company may not be representative of the corporate governance practices of the country. Future research can consider the study of more companies. Second, this study was done in Barbados, which is an emerging economy. This study did not test for specific country characteristics such as culture which may impact corporate governance practices. Future research could include examining the impact of culture (at both the national level as well as the organizational level) on corporate governance. Third, the study did not explore the board room dynamics and the influence on decision making. Future research could examine the interactions and dynamics of boards of directors in terms of how they govern the organization. In addition, more work is needed to understand how boards attempt to fulfill their governance roles.

\section{REFERENCES}

1. Abdullah, S. N. (2004). Board composition, CEO duality and performance among Malaysian listed companies. Corporate Governance: The International Journal of Business in Society, 4(4), 47-61.

2. Agrawal, A., \& Chandra, A. (2005). Corporate governance and accounting scandals. Journal of Law and Economics, 111, 370-406. https://doi.org/10.1086/430808

3. Akpan, E. O., \& Amran, N. A. (2014). Board characteristics and company performance: Evidence from Nigeria. Journal of Accounting and Finance, 2(3), 81-89. https://doi.org/10.11648/j.jfa.20140203.17

4. Alleyne, P. (2010). The influence of individual, team and contextual factors on external auditors' whistleblowing intentions in Barbados. (PhD thesis, School of Management, University of Bradford). Retrieved from https://core.ac.uk/reader/137224

5. Alleyne, P., Howard, M., \& Greenidge, D. (2006). The role of audit committees in Barbados. Corporate Governance the International Journal of Business in Society, 6(5), 567-581. https://doi.org/10.1108/14720700610706063

6. Alleyne, P., \& Chandler, M. (2018). Examining the potential impact of whistleblowing on corruption in the Caribbean's financial sector. In O. Hawthrone, \& S. Magu. (Eds.), Corruption Scandals and their Global Impacts (pp.34-56). London: Routledge.

7. Alleyne, P., \& Pierce, A. (2017). Whistleblowing as a corporate governance mechanism in the Caribbean. In A. Bissessar, \& S. Ryan. (Eds.), Snapshots in Governance: The Caribbean Experience (pp. 176-198). University of the West Indies.

8. Alleyne, P., Weekes-Marshall, D., \& Broome, T. (2014). Accountants' perceptions of corporate governance in public limited liability companies in emerging economy: Evidence from Barbados. Meditari Accountancy Research, 22(2), 186-210. https://doi.org/10.1108/MEDAR-09-2013-0039

9. Arora, A., \& Sharma, C. (2016). Corporate governance and firm performance in developing countries: Evidence from India. Corporate Governance: The International Journal of Business in Society, 16(2), 420-436. https://doi.org/10.1108/CG-01-2016-0018

10. Arslan, O., Karan, M. B., \& Eksi, C. (2010). Board structure and corporate performance. Managing Global Transitions, 8(1), 3-22.

11. Becht, M., Bolton, P., \& Roell, A. (2005). Corporate governance and control (Working Paper No.02/2002). France: European Corporate governance Institute.

12. Berle, A., \& Means, G. (1932). The modern corporation and private property. New York: Macmillan.

13. Bhagat, S., \& Black, B. (1999). The uncertain relationship between board composition and firm performance. Business Lawyer, 54, 921-963.

14. Bhagat, S., \& Black, B. (2001). The non-correlation between board independence and long-term firm performance. Journal of Corporation Law, 27, 231-273.

15. Brickley, J. A., Coles, C. J., \& Gregg, J. (1997). Leadership structure: Separating the CEO and chairman of the board. Journal of Corporate Finance, 3, 189-220. https://doi.org/10.1016/S0929-1199(96)00013-2

16. Cadbury Report (1992). The financial aspects of corporate governance. London: Gee and Co. Ltd.

17. Caribbean360. (2018). Replacement for CLICO launched in Barbados - and it's promising long awaited payouts soon. Retrieved from http://www.caribbean360.com/business/ replacement-clico-launched-barbadospromising-long-awaited-payouts-soon

18. Chen, V. Z., Li, J. I., \& Shapiro, D. M. (2011). Are OECD-prescribed "good corporate governance practices" really good in an emerging economy? Asia Pacific Journal of Management, 28, 115-138. https://doi.org/10.1007/s10490-010-9206-8

19. Cucinelli, D. (2013). The impact of board diversity on operating performance and firm market risk: Evidence from the Italian market. Corporate Ownership and Control, 10(2), 91-103. https://doi.org/10.22495/cocv10i2art7

20. Dalton, D. R., Daily, C. M., Ellstrand, A. E., \& Johnson, J. L. (1998). Meta-Analytic reviews of board, composition, leadership structure and financial performance. Strategic Management Journal, 19, $269-290$. https://doi.org/10.1002/(SICI)1097-0266(199803)19:3<269: AID-SMJ950>3.0.CO;2-K

21. Deloitte. (2011). Deloitte forensic audit of CLICO International Life Insurance Limited. Retrieved from http://bajan.files.wordpress.com/2012/07/clico-judicial-report.pdf.

22. Deloitte. (2013a). Report to the High Court of Barbados. CLICO Life International Life Insurance Limited. Retrieved from http://www.thebipa.net/wp-content/uploads/ 2015/05/cil- court-report-june-14-2013-final.pdf

23. Deloitte. (2013b). Deloitte forensic audit of CLICO international life insurance Ltd (under Judicial Management). Retrieved from https://bajan.files.wordpress.com/2012/07/clico-judicial-report.pdf

$$
\text { VIRTUS }
$$


24. Eisenberg, T., Sundgren, S., \& Wells, M. (1998). Larger board size and decreasing firm value in small firms. Journal of Financial Economics, 48, 35-54. https://doi.org/10.1016/S0304-405X(98)00003-8

25. Fama, E. F., \& Jensen, M. C. (1983). Separation of ownership and control. Journal of Law and Economics, 26(2), 301-325. https://doi.org/10.1086/467037

26. Forbes, D., \& Milliken, F. (1999). Cognition and corporate governance: Understanding boards of directors as strategic decision-making groups. Academy of Management Review, 24(3), 489-505. https://doi.org/10.5465/amr.1999.2202133

27. Government of Barbados. (2001). Companies Act-Cap 308. Retrieved from: http://ctrc. sice.oas.org/investment/NatLeg/Bar/Comp_act.pdf

28. Greenbury, R. (1995). Report on directors pay. London: Gee

29. Hassan, A., Karbhari, Y., Isa Mohamad, A., \& Razak, N. (2017). Board attributes and performance of government-linked companies (GLCS): Evidence from an emerging economy. Corporate Ownership and Control, 14(3), 74-83. https://doi.org/10.22 495/cocv14i3art8

30. Hermalin, B., \& Weisbach, M. (1991). The effect of board composition and direct incentives on firm performance. Financial Management, 20, 101-112. https://doi.org/10.2307/3665716

31. Higgs, D. (2003). Review of the role and effectiveness of non-executive directors. Retrieved from http://www.ecgi.org/codes/documents/higgsreport.pdf

32. Iqbal, S., Nawaz, A, \& Ehsan, S. (2019). Financial performance and corporate governance in microfinance: Evidence from Asia. Journal of Asian Economics, 60, 1-13.

33. Jensen, M. (1993). The modern industrial revolution, exit, and the failure of internal control systems. The Journal of Finance, 48(3), 831-880. https://doi.org/10.1111/j.1540-6261.1993.tb04022.x

34. Jensen, M. C., \& Meckling, W. H. (1976). Theory of the firm: managerial behavior, agency costs and ownership structure. Journal of Financial Economics, 3(4), 305-360. https://doi.org/10.1016/0304405X(76)90026-X

35. Kiel, G. C., Nicholson, \& Gavin. (2003). Board composition and corporate performance: How the Australian experience informs contrasting theories of corporate governance. Corporate governance an International Review, 11(3), 189-205. https://doi.org/10.1111/1467-8683.00318

36. Klein, A. (1998). Affiliated directors: Puppets of management or effective directors. Retrieved from https://papers.ssrn.com/sol3/papers.cmf?abstract_id=10569

37. Lam, T., \& Lee, S. (2012). Family ownership, board committees and firm performance: Evidence from Hong Kong. Corporate Governance: The International Journal of Business in Society, 12(3), 353-366. https://doi.org/10.1108/14720701211234609

38. Layne, W. (2010). Recent financial failures in the Caribbean - What were the causes and what lessons can be learnt? Retrieved from https://barbadosunderground.filewordpress.com/2012/03/financial_crisis_ in_the_caribbean.pdf

39. Lee, K. W., Lev, B. I., \& Yeo, G. H. H. (2008). Executive pay dispersion, corporate governance and firm performance. Review of Quantitative Finance and Accounting, 30, 315-338. https://doi.org/10.1007/s11156007-0053-8

40. Lipton, M., \& Lorsch, J. (1992). A modest proposal for improved corporate governance. Business Lawyer 48, 59-77.

41. McMullen, D. A. (1996). Audit committee performance: An investigation of the consequences associated with audit committees. Auditing: A Journal of Practice and Theory, 15(1), 87-103.

42. Miller, D., \& Sardais, C. (2011). Angel agents: Agency theory reconsidered. Academy of Management Perspectives, 25(2), 6-13. https://doi.org/10.5465/amp.25.2.6

43. Miyienda, B., Oirere, C. O., \& Miyogo, J. (2013). The relationship between directors remuneration and performance measure of firms listed in the Nairobi securities exchange. The International Journal of Social Sciences, 15(1), 1-17.

44. Moreno-Gómez, J., Lagos, D., \& Gómez-Betancourt, G. (2017). Effect of the board of directors on firm performance. International Journal of Economic Research, 14(6), 349-361.

45. Nazir, M. S., Ali, S., \& Haque, A. (2009). Can board mechanisms affect the firm value in Pakistan? Corporate Ownership and Control, 6(3), 308-317. https://doi.org/10.22495/cocv6i3c2p5

46. Nielsen, S., \& Huse. M. (2010). The contribution of women on boards of directors: going beyond the surface. Corporate Governance: An International Review, 18(2), 136-148. https://doi.org/10.1111/j.14678683.2010.00784.x

47. Ntim, C. G., Opong, K. K., \& Danbolt, J. (2015). Board size, corporate regulations and firm valuation in an emerging market: A simultaneous equation approach. International Review of Applied Economics, 29, 194-220. https://doi.org/10.1080/02692171.2014.983048

48. Paniagua, J., Rivelles, R., \& Sapena, J. (2018). Corporate governance and financial performance: The role of ownership and board structure. Journal of Business Research, 89, $229-234$. https://doi.org/10.1016/j.jbusres.2018.01.060

49. OECD. (2004). Principles of corporate governance. Paris: OECD Publications.

50. Okpara, J. O. (2011). Corporate governance in a developing economy: Barriers, issues and implications for firms. Corporate governance: The international journal of business in society, 11(2), 184-199. https://doi.org/10.1108/14720701111121056

51. Pass, C. (2004). Corporate governance and the role of non-executive directors in large UK companies: An empirical study. The International Journal of Business in Society, 4(2), 52-63. https://doi.org/10.1108/14720700410534976

52. Pearce, J. A., \& Zahra, S. (1992). Board composition from a strategic contingency perspective. Journal of Management Studies, 29(4), 411-438. ～https://doi.org/10.1111/j.1467-6486.1992.tb00672.x

53. Rafiee, V. B., \& Sarabdeen, J. (2012). Cultural influence in the practice of corporate governance in emerging markets. Communications of the IBIMA, 1, 1-12. https://doi.org/10.5171/2012.444553

54. Rashid, A. (2010). CEO duality and firm performance: Evidence from a developing country. Corporate Control \& Ownership, 8(1), 163-175. https://doi.org/10.22495 /cocv8ilclp1

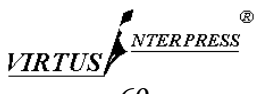


55. Sarhan, A., Ntim, C., \& Al-Najjar, B. (2018). Board diversity, corporate governance, corporate performance, and executive pay. International journal of Finance \& Economics, 24(2), 761-786. https://doi.org/10.1002/ijfe.1690

56. Shleifer, A., \& Vishny, R. W. (1997). A survey of corporate governance. The Journal of Finance, 737-783. https://doi:10.1111/j.1540-6261.1997.tb04820.x

57. Smith, N., Smith, V., \& Verner, M. (2005). Do women in top management affect firm performance? A panel study of 2,500 Danish firms. Copenhagen: Centre for Industrial Economics, University of Copenhagen.

58. Solomon, J., \& Solomon, A. (2004). Corporate governance and accountability. John Wiley, New York, NY.

59. Sookram, R. (2016). Corporate governance in the emerging economies of the Caribbean: Peculiarities, challenges, and a future pathway. The Journal of Values-Based Leadership, 9(1), 1-19.

60. Soverall, C. (2012). Clico's collapse: Poor corporate governance. American International Journal of Contemporary Research, 2(2), 166-178.

61. Soverall, W., \& Persaud, W. (2013). A study of corporate failure and the political economy of financial regulation in Trinidad and Tobago and the Caribbean. International Journal of Humanities and Social Science, 3(16), 17-28.

62. Stabroek News. (2009). CLICO (Barbados) Statutory fund in deficit - Mottley. Retrieved from https://www.stabroeknews.com/2009/news/regional/02/23/clico-barbados-statutory- fund-in-deficit-mottley/

63. Stabroek News. (2013). Barbados policy holders to sue CLICO directors. Retrieved from https:www.Stabroeknews.com/2013/news/regional/01/27/barbados-policyholders-to-sue-clico- directors/

64. Tricker, B. (2015). Corporate governance, principles, policies and practices. The United Kingdom: Oxford University Press.

65. Tsamenyi, M., Enninful-Adu, E., \& Onumah, J. (2007). Disclosure and corporate governance in developing countries: Evidence from Ghana. Managerial Auditing Journal, 22(3), 319-334. https://doi.org/10.1108/02686900710733170

66. Ujunwa, A. (2012). Board characteristics and financial performance of Nigerian quoted firms. Corporate governance, 12(5), 656-674. https://doi.org/10.1108/14720701211275587

67. Ujunwa, A., Nwakoby, I., \& Ugbam, C. O. (2012). Corporate board diversity and firm performance: Evidence from Nigeria. Corporate Ownership and Control, 9(2-1), 216-226. https://doi.org/10.22495/cocv9i2clart6

68. Wachudi, J. E., \& Mboya, J. (2012). Effect of board gender diversity on the performance of commercial banks in Kenya. European Scientific Journal, 8(7), 128-148.

69. Wood, A., \& Wood, T. (2013). Emera's takeover of light and power holdings limited: A case study in corporate governance and takeovers in the Caribbean. International Journal of Arts and Commerce, 2(1), 27-48.

70. Yermack, D. (1996). Higher market valuation of companies with a small board of directors. Journal of Financial Economics, 40, 185-211.

71. Zubaidah, Z. A., Nurmala, M. K., \& Kamaruzaman, J. (2009). Board structure and corporate performance in Malaysia. International Journal of Economics and Finance, 1(1), 150-164. https://doi.org/10.1016/0304405X(95)00844-5 